\title{
Corrosion Resistance of 1.4362 Steel in Boiling $65 \%$ Nitric Acid
}

\section{Tomasz Lipiński}

University of Warmia and Mazury in Olsztyn, Faculty of Technical Sciences, Department of Material and Machine Technology, Oczapowskiego 11, 10-957 Olsztyn, Poland. E-mail: tomekl@uwm.edu.pl

Lean duplex stainless steels were developed for use in environments where high strength and corrosion resistance are required. Duplex stainless steels offer a cost-effective solution with high strength and corrosion resistance. Due to high chromium content and a balanced composition, $\mathbf{1 . 4 3 6 2}$ ferritic-austenitic stainless steel possesses excellent corrosion resistance in acidic environments. General corrosion problems in duplex stainless steels at $475^{\circ} \mathrm{C}$ have been widely researched. Steels are most degraded at $475^{\circ} \mathrm{C}$, but corrosion can still occur at both lower and higher temperatures. Corrosion resistance is influenced by chromium content and microstructural morphology. The percentage of each phase and its properties are determined by composition, technological processing and heat treatments. Machining and fabrication practices, such as welding, are also vital for performance. The objective of this study was to determine the effects of 30-minute isothermal heat treatments at $535^{\circ} \mathrm{C}$ and exposure time on relative mass loss and roughness parameters of 1.4362 lean duplex stainless steel. The influence of boiling nitric acid on the corrosion resistance of steel was investigated based on mass loss and roughness parameters. Corrosion properties and roughness of 1.4362 alloys are discussed in this paper.

Keywords: stainless steel, duplex steel, corrosion, corrosion rate, profile roughness

\section{References}

[1] ŁABANOWSKI, J., ŚWIERCZYŃSKA, A., TOPOLSKA, S. (2014). Effect of microstructure on mechanical properties and corrosion resistance of 2205 duplex stainless steel. In: Polish Maritime Research 4/84, pp. 108-112.

[2] SZABRACKI, P., LIPIŃSKI, T. (2014). Influence of sigma phase precipitation on the intergranular corrosion resistance of X2CrNiMoN25-7-4 super duplex stainless steel. In: 23rd International Conference on Metallurgy and Materials METAL 2014, pp. 476-481.

[3] DUDEK, A., WROŃSKA, A., ADAMCZYK, L. (2014). Surface remelting of 316 L+434 L sintered steel: microstructure and corrosion resistance. In: Journal Solid State Electronics 18/11, pp. 2973-2981.

[4] BASTOS, I., TAVARES, S., DALARDA, F., NOGUEIRA, R. (2007). Effect of microstructure on corrosion behavior of superduplex stainless steel at critical environment conditions. In: Scripta Materiala 57/10, pp. 913-916.

[5] SZABRACKI, P., JASKÓLSKI, M., LIPIŃSKI, T., KACZMAREK-KACPRZAK, A. (2014). The FEM analysis of pressure installation elements after simulated accidental overheating. In: Recent Advances in Computational Mechanics, pp. 311-317. CRC Press Taylor \& Francis Group A Balkema Book London.

[6] TAVARES S., PARDAL J., LIMA L.D., BASTOS, I.N., NASCIMENTO, A.M., DE SOUZA J. (2007). Characterization of microstructure, chemical composition, corrosion resistance and toughness of a multipass weld joint of superduplex stainless steel UNS S32750. In: Material Characterizations 58/7, pp. 610-616.

[7] SZABRACKI, P., LIPIŃSKI, T. (2013). Effect of aging on the microstructure and the intergranular corrosion resistance of X2CrNiMoN25-7-4 duplex stainless steel. In: Solid State Phenomena 203-204, pp. 59-62.

[8] PETROVIC, D.S., PIRNAT, M., KLANCNIK, G., MRVAR, P., MEDVED, J. (2012). The effect of cooling rate on the solidification and microstructure evolution in duplex stainless steel. A DSC study. In: Journal of Thermal Analysic and Calorimetry 109, pp. 1185-1191.

[9] GĄ $\square$ IOR, W., DĘB $\square$ KI, A., GÓRAL, A., MAJOR, R. (2014). Enthalpy of formation of intermetallic phases from Al-Li system by solution and direct reaction calorimetric method. In: Journal of Alloy Compounds 586, pp. 703708 .

[10] MICHNA, Š., NÁPRSTKOVÁ, N. (2009). Vliv vnějších faktorů na korozní poškození hliníkových polotovarů, In: Strojírenská technologie, XIV/2, str. 17-21. FPTM JEPU, Usti nad Labem, Czech Republic.

[11] SZABRACKI, P., LIPIŃSKI, T. (2013). Effect of aging on the microstructure and the intergranular corrosion resistance of X2CrNiMoN25-7-4 duplex stainless steel. In: Solid State Phenomena 203-204, pp. 59-62.

[12] KUSMIERCZAK, S. (2015). Evaluation of Degradation of Heat Stressed Pipelines. In: Manufacturing Technology Vol 15, No 6, p. 1006-1010.

[13] POHL, M., STORZ, O., GLOGOWSKI, T. (2007). Effect of intermetallic precipitations on the properties of duplex stainless steel. In: Material Characterizations 58, pp. 65-71. 
[14] PIETRASZEK, J., GADEK-MOSZCZAK, A. (2013). The smooth bootstrap approach to the distribution of a shape in the ferritic stainless steel AISI 434L powders. In: Solid State Phenomena 197, pp. 162-167.

[15] NOVAK, M., (2011). Surface quality of hardened steels after grinding. In: Manufacturing Technology Vol 11, No 11, p. 55-59.

[16] PITRMUC, Z., CAPEK, J., KOLARIK, K., BERANEK, L., URBAN, J. (2016). Tool Geometry Influence on Surface Integrity of Machined Austenite Stainless Steel. In: Manufacturing Technology Vol. 16, No. 2, pp. 425431.

[17] NOVÁ, I., MACHUTA, J. (2016). Monitoring of the Diffusion Processes during Carburizing Automotive Steel Parts. In: Manufacturing Technology Vol 16, No 1, p. 225-230.

[18] KOVALČÍK, T., STOULIL, J., SLÁMA, P., DALIBOR, V. (2015). The Influence of Heat Treatment on Mechanical and Corrosion Properties of Wrought Aluminium Alloys 2024 and 6064. In: Manufacturing Technology Vol 15, No 1, p. 54-61.

[19] KOVALČÍK, T., STOULIL, J., SLÁMA, P. DALIBOR, V. (2015). The Influence of Heat Treatment on Mechanical and Corrosion Properties of Wrought Aluminium Alloys 2024 and 6064. In: Manufacturing Technology Vol 15, No 1, p. 148-155.

[20] HOTAR, A., HOTAR, V. (2015). Fractal Geometry Used for Evaluation of Corrosion Resistance of Fe-14Al-6Cr Wt. \% against Molten Glass. In: Manufacturing Technology Vol 15, No 4, p. 534-541.

[21] LIPTÁKOVÁ, T., LOVÍŠEK, M., HADZIMA, B. (2015). Parameters Affected Corrosion and Mechanical Properties of Al-Brasses. In: Manufacturing Technology Vol 15, No 4, p. 587-591.

[22] LIPIŃSKI, T. (2016). Corrosion of X2CrNiMoSi18-5-3 Duplex Stainless Steel. In: 15th International Scientific Conference Engineering for Rural Development, Proceedings vol. 15, Jelgava, 25.-27.05. pp. 946-951.

[23] SELEJDAK, J., ULEWICZ, R., INGALDI, M. (2014). The evaluation of the use of a device for producing metal elements applied in civil engineering. In: 23rd International Conference on Metallurgy and Materials METAL, pp. 1882-1888.

[24] SCENDO, M., RADEK, N., TRELA, J. (2013). Influence of laser treatment on the corrosive resistance of Wc-Cu coating produced by electrospark deposition. In: International Journal Electrochemical Sciences 8, pp. 9264-9277.

[25] STEINER PETROVIC, D., PIRNAT, M., KLANCNIK, G., MRVAR, P., MEDVED, J. (2012). The effect of cooling rate on the solidification and microstructure evolution in duplex stainless steel. In: Journal of Thermal Analysic and Calorimetry 109, pp. 1185-1191.

[26] SVOBODOVÁ, J., CAIS, J., MICHNA, Š., BRU゚HA, M. (2013). Research of Corrosion Properties of Al-Si Alloys Antimony Alloyed. In: Manufacturing Technology Vol 13, No 3, p. 404-409.

[27] ANGELINI, E., DE BENEDETTI, B., ROSALBINO, F. (2004). Microstructural evolution and localized corrosion resistance of an aged superduplex stainless steel. In: Corrosion Science 46/6, pp. 1351-1367.

[28] KUŚMIERCZAK, S., SVOBODOVÁ, J. (2012). Microscopic Evaluation of Protective Coating by Coated Sheets after Corrosion Load. In: Manufacturing Technology Vol 12, No 13, p. 151-157.

[29] WOŁCZYŃSKI, W., GUZIK, E., WAJDA, W., JEDRZEJCZYK, D., KANIA, B., KOSTRZEWA, M. (2012). Cet in solidifying roll-thermal gradient field analysis. In: Archives of Metallurgy and Materials 57/1, pp. 105-117.

[30] ULEWICZ, R. (2003). Quality control system in production of the castings from spheroid cast iron. Metalurgija In: Metalurgija 42/1, pp. 61-63.

[31] SEJČ, P., KUBÍČEK, R. (2015). Analysis of Arc Stability in MIG Brazing of 304L Stainless Steel Using Solid and Flux-Cored Wire. In: Manufacturing Technology Vol 15, No 1, p. 86-92.

[32] DUBOVSKA, R., MAJERIK, J. (2015). Experimental Investigation and Analysis of Cutting Forces When Machining X5CrNi18-10 Stainless Steel. In: Manufacturing Technology Vol 15, No 3, p. 322-329.

[33] KROLCZYK, G., LEGUTKO, S. (2013). The Machinability of Duplex Stainless Steel - Solutions in Practice. In: Manufacturing Technology Vol 13, No 4, p. 473-478.

[34] ZATKALÍKOVÁ, V., MARKOVIČOVÁ, L., BELAN, J., LIPTÁKOVÁ, T. (2014). Variability of Local Corrosion Attack Morphology of AISI 316Ti Stainless Steel in Aggressive Chloride Environment. In: Manufacturing Technology Vol 14, No 3, p. 493-497.

[35] NOVOTNÝ, J., HONZÍKOVÁ, J., PILOUS, V., STRÁNSKÝ, K. (2015). Properties of Welded Joints in Power Plant. In: Manufacturing Technology Vol 15, No 6, p. 1028-1032. 
[36] HRUBÝ, J., SCHINDLEROVÁ, V. (2015). Degradation Processes in the Contact Layers of Forming Tools. In: Manufacturing Technology Vol 15, No 5, p. 836-842.

[37] ANTONY, P.J., CHONGDAR, S., KUMAR, P., RAMAN, R. (2007). Corrosion of 2205 duplex stainless steel in chloride medium containing sulfate-reducing bacteria. In: Electrochimica Acta 52/12, pp. 3985-3994.

[38] ODEHNAL, J., BROTÁNEK, S. (2013). Metallurgical and Material Properties of Castings Manufactured from Stainless G-X4CrNi13-4 and GX4CrNiCu13-4. In: Manufacturing Technology Vol 13, No 1, p. 85-91.

[39] WŁODARCZYK, R., DUDEK, A., NITKIEWICZ, Z. (2011). Corrosion analysis of sintered material used for low-temperature fuel cell plates. In: Archives of Metallurgy and Materials 59/1, pp. 135-140.

[40] KUSMIC, D., DOBROCKY, D. (2015). Corrosion Resistance of Plasma Nitrided Structural Steels. In: Manufacturing Technology Vol 15, No 1, p. 64-69.

[41] DALIBOR, V., KUBÁSEK, J., NOVÁK, P. (2013). Corrosion properties of the superelastic shape memory Ni-Ti alloy for medical implants. In: Manufacturing Technology Vol 14, No 3, p. 409-414.

[42] WHARTON, J.A., WOOD, R.J.K., MELLOR, B.G. (2003). Wavelet analysis of electrochemical noise measurements during corrosion of austenitic and superduplex stainless steels in chloride media. In: Corrosion Science 45, pp. $97-122$.

[43] NOVAK, M., NAPRSTKOVA, N. (2015). Grinding of the Alloy INCONEL 718 and Final Roughness of the Surface and Material Share. In: Manufacturing Technology Vol 15, No 6, p. 1015-1023.

[44] NOVAK, M., KASUGA, H., OHMORI, H. (2013). Differences at the Surface Roughness by the ELID and Grinding Technology. In: Manufacturing Technology Vol 13, No 2, p. 210-215. 